\title{
Welcome in my backyard: how having good neighbours can help ending homelessness
}

\author{
Maarten Davelaar ${ }^{1}$, Lia van Doorn ${ }^{2}$, Aly Gruppen ${ }^{3}$, Jeroen Knevel ${ }^{4}$ \\ ${ }^{1}$ Centre for Social Innovation, HU University of Applied Sciences Utrecht, NL, ${ }^{2}$ Centre for \\ Social Innovation, HU University of Applied Sciences Utrecht, NL, ${ }^{3}$ Centre for Social \\ Innovation, HU University of Applied Sciences Utrecht, NL, ${ }^{4}$ Centre for Social Innovation, \\ HU University of Applied Sciences Utrecht, NL.
}

\begin{abstract}
With the goal of drawing lessons from collective mixed housing projects in Utrecht, the HU University of Applied Sciences Utrecht, created in partnership with care and housing providers a Community of Practice on Mixed Housing. Residents of housing projects, social workers, community builders and managers of housing associations, care providers and homeless organisations participated in this learning community. The research conducted within the framework of this Community of Practice reveals the positive impact of three projects housing ex-homeless people on the individual wellbeing of most inhabitants. Furthermore, the research underlines the potential of these innovative projects to scale up affordable and adequate housing for both (young) people entering the housing market and people previously depending on protected housing facilities, institutions or shelters. Lessons learned from the projects have been incorporated in (plans for) new mixed housing projects. These include a set of conditions under which mixed housing projects can help care providers, homeless services, housing corporations and local authorities to secure a good living environment for all - including those living close to these housing projects.
\end{abstract}

Keywords: Inclusive housing policies, collective mixed housing projects, homelessness, community building. 


\section{Introduction}

In the Netherlands, the city of Utrecht is leading in providing adequate accommodation through mixed housing projects for 'regular' tenants and people previously living in homeless services or protected housing facilities. 'New' homeless persons also obtain the possibility for making a new start, instead of having to depend on shelters first. The concept of mixed housing, not to be confused with mixed income housing, relates in our definition to small and medium-sized (up to 500 residents) collective housing projects that are home to different groups of people, including more vulnerable and/or socially excluded groups. They intentionally live next to each other, connect and engage in joint activities.

In this paper, we examine in detail three projects, all with mainly self-contained dwellings: 'Groene Sticht' (since 2003), a small neighbourhood with 69 regular tenants and homeowners, and 35 ex-homeless persons; 'Parana' (2014), a purpose build complex with 24 regular and 44 (ex-)homeless individuals/families; 'Majella Wonen' (2016), older basic, post-war dwellings with 39 regular tenants and 35 homeless persons/families (see table 1 for an overview of the main characteristics of the housing projects and figure 1 for some images). These price-winning projects, co-created by a homeless service, social integration services and a social housing provider are built on an innovative concept of social management, with a high level of self-organisation. All residents are fully eligible members of the residentscommittees and take responsibility for activities such as festivities, gardening, and the selection of new tenants. If necessary, ex-homeless inhabitants receive individualised support.

\section{Research within the framework of a Community of Practice}

In 2016 a Community of Practice on mixed housing was created in Utrecht. It is best described as a learning community with residents of housing projects, social workers and community builders and policy makers and managers of housing associations, care providers and homeless organisations. The Community of Practice was facilitated by the Centre of Social Innovation of HU University of Applied Sciences. Research was conducted within the framework of this Community. We collected data (2016 -2018) through the participatory meetings of this Community of Practice on Mixed housing, the study of documents, in-depth interviews with inhabitants of the housing complexes, focus group-sessions with professionals and interviews with local stakeholders. The research findings were thoroughly discussed during the meetings of the learning community.

Our research focused on the following questions: what are social structures and mechanisms that could help create a socially sustainable, safe and attractive living environment for both regular tenants and more vulnerable populations? What obstacles seem to hamper inclusion and participation or create tensions between residents from different backgrounds? Could lessons learned from existing mixed housing projects be used to develop new projects and 
improve policies aiming at creating more inclusive and welcoming neighbourhoods? In this paper we discuss in detail structures and mechanisms that help homeless people feel at home amidst their (new) neighbours and foster their social integration. In addition, we identify several tensions that hamper integration and analyse the ways in which both residents and professionals try to tackle these obstacles. We pay attention to the lessons learned in the Community of Practice and the ways in which new insights are implemented in the three housing projects mentioned before. We also describe how new understandings have influenced working practices in Place2BU, one of the latest, and up until now the largest, collective mixed housing project in Utrecht (see table 1 and figure 1). We will also describe how the Community of Practice and a newly created course for social workers, project managers and others working for mixed housing projects or planning to create new ones, generates ideas for the benefit of future mixed housing projects in particular, and inclusive housing policies in general.

\section{Results and conclusions}

Our findings can be summarized as follows: first, these innovative projects increase the wellbeing of most inhabitants: people report 'feeling at home', less lonely and being accepted. The friendly interactions, mutual self-help and possibility to engage in activities are mentioned as valuable characteristics. Accordingly, the former homeless people, often also with a history of mental illness or addictions, tend to ask for support at an early stage, with the community functioning as a social 'early warning system'. Furthermore, the research underlines the potential of these innovative projects to scale up affordable and adequate housing for both (young) people entering the housing market and people previously depending on protected housing facilities, institutions or shelters. Lessons learned from the projects have been incorporated in (plans for) new mixed housing projects. To end with, we identified conditions under which mixed housing projects can help care providers, homeless services, housing corporations and local authorities to secure a good living environment for all - including those living close to these housing projects. Crucial aspects seem to be the existence of a social management policy including a clear vision on self-organisation and community building, smart selection procedures with expectation-management to foster a realistic level of reciprocity and the availability of individualised professional support when needed.

\section{Exchange of ideas and further research}

We are curious to hear from other examples and experiences related to integrative and inclusive developments in the social housing sector, including initiatives by tenants themselves. Based on our research we will search for follow up funding through national funds and European funds. For that purpose we hope to get in touch with researchers in the 
CARPE-network who are interessed in developing new proposals in the field of innovative, inclusive housing policies and practices.

Table 1. Characteristics of some mixed housing projects in Utrecht ${ }^{1}$

\begin{tabular}{|c|c|c|c|c|}
\hline $\begin{array}{c}\text { Mixed Housing } \\
\text { projects in } \\
\text { Utrecht }\end{array}$ & Regular tenants & $\begin{array}{l}\text { Tenants from } \\
\text { 'special target } \\
\text { groups' }\end{array}$ & Type of dwellings & Facilities \\
\hline $\begin{array}{c}\text { 't Groene Sticht } \\
\text { (since 2003) Small } \\
\text { neighbourhood in } \\
\text { new large city } \\
\text { district }\end{array}$ & $\begin{array}{c}69 \text { (including } \\
\text { families and single } \\
\text { person households, } \\
3 \text { members } \\
\text { Emmaus } \\
\text { community and } \\
\text { appr. } 12 \text { home- } \\
\text { owners) }\end{array}$ & $\begin{array}{l}35 \text { ex-homeless } \\
\text { people (including } \\
10 \text { people living in } \\
\text { the Emmaus } \\
\text { community) }\end{array}$ & $\begin{array}{l}32 \text { self-contained } \\
\text { apartments, } 9 \\
\text { rooms, } 1 \text { Emmaus- } \\
\text { group, } 9 \text { owner- } \\
\text { occupied } \\
\text { properties }\end{array}$ & $\begin{array}{l}\text { Offices for floating } \\
\text { support workers, } \\
\text { meeting spaces, } \\
\text { garden, } \\
\text { neighbourhood } \\
\text { restaurant, second- } \\
\text { hand shop }\end{array}$ \\
\hline $\begin{array}{c}\text { Parana (since } \\
\text { 2014) Purpose } \\
\text { build complex } \\
\text { under architecture }\end{array}$ & $\begin{array}{c}24 \text { (including } \\
\text { students and young } \\
\text { working people) }\end{array}$ & $\begin{array}{c}20 \text { people in } \\
\text { emergency } \\
\text { services, } 24 \text { 'multi- } \\
\text { problem', ex- } \\
\text { homeless people }\end{array}$ & $\begin{array}{l}48 \text { apartments (one } \\
\text { and two rooms, } \\
\text { including bath- } \\
\text { room and kitchen) }\end{array}$ & $\begin{array}{c}\text { Communal } \\
\text { kitchens, living } \\
\text { rooms and rooftop } \\
\text { garden, Kiosk, } \\
\text { offices (24/7 staff) }\end{array}$ \\
\hline $\begin{array}{c}\text { Majella (since } \\
\text { 2016) Older, basic, } \\
\text { post-war dwellings }\end{array}$ & $\begin{array}{c}39 \text { (mainly } \\
\text { working people, } \\
\text { few students) }\end{array}$ & $\begin{array}{l}35 \text { ex-homeless } \\
\text { people (including } \\
\text { some families) }\end{array}$ & $\begin{array}{l}67 \text { apartments (one } \\
\text { and two rooms, } \\
\text { plus bathroom and } \\
\text { kitchen) }\end{array}$ & $\begin{array}{l}\text { Office for floating } \\
\text { support workers } \\
\text { (will be } \\
\text { transformed in } \\
2020 \text { into } \\
\text { communal space), } \\
\text { garden }\end{array}$ \\
\hline $\begin{array}{l}\text { Place2BU (since } \\
\text { 2017) temporary, } \\
\text { prefabricated, } \\
\text { modular housing }\end{array}$ & 360 (all under 27) & $\begin{array}{l}90 \text { ex-homeless } \\
\text { people and clients } \\
\text { from supported } \\
\text { housing schemes, } \\
40 \text { young refugees }\end{array}$ & $\begin{array}{l}490 \text { apartments } \\
\text { (including } \\
\text { bathroom and } \\
\text { kitchenette) }\end{array}$ & $\begin{array}{c}\text { Small communal } \\
\text { living room on } \\
\text { each floor, large } \\
\text { community centre, } \\
\text { sports grounds, } \\
\text { gardens }\end{array}$ \\
\hline
\end{tabular}

\footnotetext{
${ }^{1}$ Figures from 2018.
} 

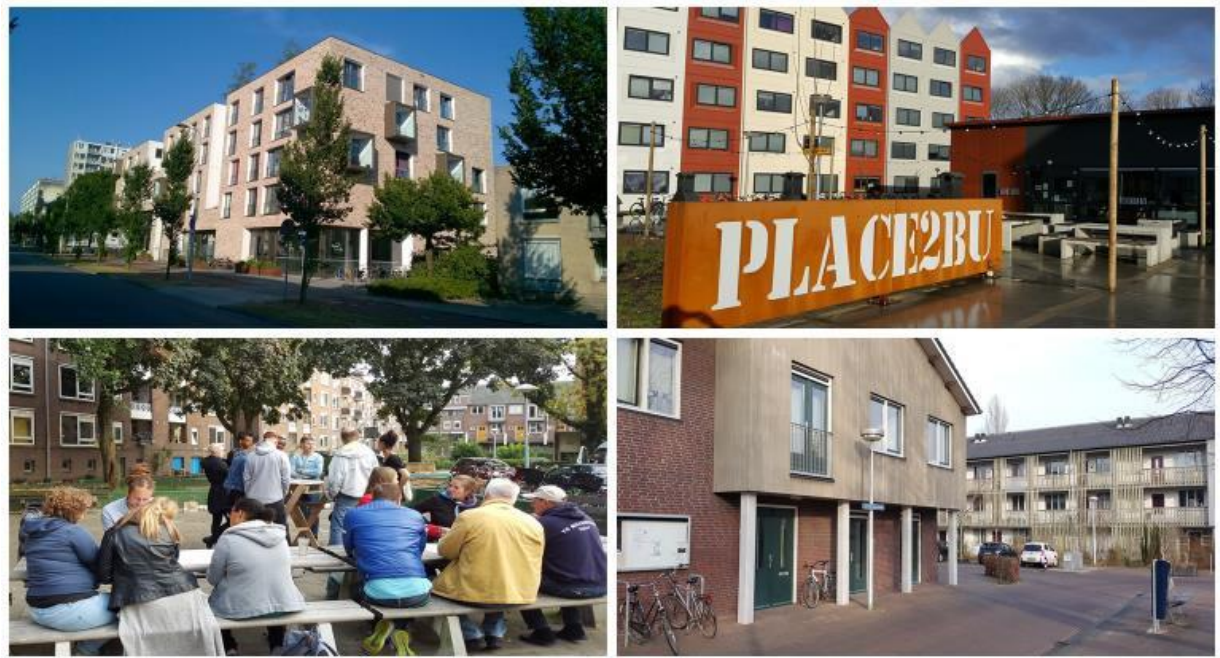

Figure 1. Mixed housing projects, clockwise from top left: Parana, Place2BU, 't Groene Sticht, Majella.

\section{References}

Davelaar, M., Gruppen, A. \& Knevel, J. (2018). Goede buren. Lessen uit gemengde woonprojecten in Utrecht. [Good neigbours. Lessons from mixed housingprojects in Utrecht.] Utrecht: Kenniscentrum Sociale Innovatie Hogeschool Utrecht. 